\title{
Characterization of Caulerpa racemosa yogurt processed using Lactobacillus bulgaricus and Streptococcus thermophilus
}

\author{
"Dewi, E.N. and Purnamayati, L. \\ Department of Fish Product Technology, Faculty of Fisheries and Marine Science, Universitas Diponegoro, \\ Jl. Prof. H. Soedarto, SH, Tembalang, Semarang 50275, Central Java, Indonesia.
}

\author{
Article history: \\ Received: 9 February 2021 \\ Received in revised form: 24 \\ March 2021 \\ Accepted: 27 March 2021 \\ Available Online: 28 July \\ 2021
}

Keywords:

Caulerpa racemosa,

Dietary fibre,

Lactic acid bacteria,

Yogurt

\section{DOI:}

https://doi.org/10.26656/fr.2017.5(S3).008

\begin{abstract}
Lactic acid bacteria such as Lactobacillus bulgaricus and Streptococcus thermophilus in yogurt maintains the balance of the intestinal microflora by suppressing the growth of harmful bacteria. Dietary fibre and functional compounds in probiotic drinks also have a good effect on health. The modification of low-fat probiotic drinks is a value-added product and can be classified as a healthy drink. Caulerpa racemosa is a Chlorophyceae seaweed with high food fibre and functional compounds, including phenolic and chlorophyll as antioxidants. This study aimed to determine the effect of different lactic acid bacteria on the characteristics of the probiotic drink products by combining $C$. racemosa with low-fat cow's milk. C. racemosa and low-fat cow's milk with a ratio of 3:4 was fermented with Lactobacillus bulgaricus (A), Streptococcus thermophilus (B), and a combination of both $(\mathrm{C})$. The products were analysed for protein and fat content, dietary fibre, total phenolic content, antioxidants activity, total lactic acid bacteria, total acid, $\mathrm{pH}$, and with a sensory test for consumer preference. The addition of the different lactic acid bacteria had effects on the fat, antioxidants, dietary fibre, and total acid contents, while protein and total phenolic contents were not significantly different. The combination of $L$. bulgaricus and $S$. thermophilus produced a probiotic drink with the lowest amount of dietary fibre (1.27\%) and total acid (0.64\%), with antioxidant activity $\mathrm{IC}_{50}$ of $183.57 \mathrm{ppm}$ and total phenolic content of $0.11 \mathrm{mg}$ GAE/g. The preference test showed that the panellists preferred yogurt fermented with L. bulgaricus and S. thermophilus for its aroma, texture, and colour.
\end{abstract}

\section{Introduction}

Caulerpa racemosa, also known as sea grape, is a green macroalga seaweed that, for human consumption, is usually served fresh or with salt (Sihono et al., 2018). C. racemosa contains bioactive components such as protein and polysaccharides, and secondary phenolic and flavonoid metabolites, namely $19.72 \%$ protein, $7.65 \%$ fat, and $11.51 \%$ fibre. It has a bright green colour (Bhuiyan et al., 2016; Sihono et al., 2018; Yap et al., 2019) and is known to have antioxidant properties. However, C. racemosa in food products is often either uncommon or sub-optimally used. Pires et al. (2013) found that polysaccharides contained in C. racemosa function as a catalyst for phospholipase enzymes and have pharmaceutical potential. As such, C. racemosa may be applied to the development of healthy foods.

Yogurt is a fermented drink known for its substantial health benefits, particularly in preventing digestive problems, boosting immunity, and increasing lactose tolerance for those who lactose intolerant. It is healthy because bacteria make it easily digestible, create a unique matrix that forms bioavailability and metabolic properties. It is satiating and good for weight control (Weerathilake et al., 2014; Rizzoli and Biver, 2017). The health benefits are what drive consumer demand, and the nutritional composition is what consumers consider first. As such, turnoffs for health-conscious consumers are fat and sugar contents, many consumers will prefer yogurt with low sugar and fat content (Miklavec et al., 2014).

Yogurt owes its healthy characteristics to bacteria that convert lactose into lactic acid, giving it a unique texture and flavour. Yogurt fermentation with lactic acid bacteria consists of glycolysis, proteolysis, and lipolysis and produces a sour taste and aroma. However, the fermentation and the formation of lactic acid are inherently linked to the quality of the bacteria (Obi et al., 2016). Lactobacillus bulgaricus and Streptococcus 
thermophilus are often used for making yogurt. These are lactic acid bacteria that play a role in converting lactose into secondary metabolite products through the heterofermentative pathway. They are known to produce lactic acid with different isomers, such as $\mathrm{D}(-)$ and $\mathrm{L}(+)$ (Corrieu and Beal, 2016; Chen et al., 2017). Agu et al. (2014), Rahman et al. (2016), and Sarvari et al. (2014) have already studied the characteristics of yogurt made with combination of L. bulgaricus and S. thermophilus. However, research on yogurt made exclusively with these lactic acid bacteria individually is rarely conducted. Therefore, this is a novel study comparing yogurt made with either a combination of $L$. bulgaricus and $S$. thermophilus or individually.

Yogurt is generally produced with cow's milk as the main ingredient. C. racemosa is added to make it rich in antioxidants and dietary fibre, also giving it a green colour. The phenolic components and secondary metabolites in $C$. racemosa survive the heating and cooling process during production (Sihono et al., 2018; Nurjanah et al., 2019). Currently, C. racemosa is rarely used as a raw material besides biscuits (Kumar et al., 2017) and jelly candy (Tapotubun et al., 2018). It is not yet used in healthy drinks such as yogurt. It was assumed that the nutrient content in $C$. racemosa degrades during the fermentation process when different lactic acid bacteria are included. The goal of this study was to determine the characteristics of low-fat cow's milk made with $C$. racemosa and fermented with different types of lactic acid bacteria.

\section{Materials and methods}

\subsection{Materials}

Ultra's low-fat cow's milk was obtained from local supermarkets in Semarang, Indonesia. Fresh $C$. racemosa was harvested in Jepara from the northern Central Java Sea, Indonesia. The commercial strains of lactic acid bacteria Lactobacillus bulgaricus FNCC 0041 and Streptococcus thermophilus FNCC 0040 were purchased from The Central of Food Research and Nutrition, Gadjah Mada University, Yogyakarta, Indonesia.

\subsection{Microbial culture preparation}

Lactobacillus bulgaricus and S. thermophilus were cultured by inoculating a loop of L. bulgaricus and $S$. thermophilus in $15 \mathrm{~mL}$ MRS agar media (Oxoid), followed by incubation at $37^{\circ} \mathrm{C}$ for $72 \mathrm{hrs}$. The inoculum was made by transferring a loop of pure culture bacteria in a $9 \mathrm{~mL}$ milk solution incubated at $37^{\circ} \mathrm{C}$ for $24 \mathrm{hrs}$.

\subsection{Caulerpa racemosa preparation}

Fresh C. racemosa was washed and cut into pieces, then chopped, mashed, and blended using a blender (Maspion, Indonesia) until homogenous. The ratio of $C$. racemosa to water was 1:9.

\subsection{Yogurt preparation}

Yogurt was produced according to Undugoda and Nilmini (2019) with some modifications. A mixture of approximately $30 \%$ C. racemosa, $40 \%$ low-fat milk, 5\% sucrose, and $20 \%$ water was pasteurized using the HTST method at $72^{\circ} \mathrm{C}$ for 15 mins. The mixture's temperature was then lowered and 5\% L. bulgaricus (A), 5\% $S$. thermophilus (B), and a mixture of $2.5 \%$ L. bulgaricus and $2.5 \% \quad S$. thermophilus (C) were added. Each treatment was then fermented for $6 \mathrm{hrs}$ at $37^{\circ} \mathrm{C}$. Finally, the yogurt was placed into glass bottles, covered with aluminium foil, and stored at $5^{\circ} \mathrm{C}$.

\subsection{Fat analysis}

The analysis was carried out according to AOAC (1992). Briefly, a $1.5 \mathrm{~mL}$ of $\mathrm{NH}_{4} \mathrm{OH}$ was added to $10 \mathrm{~g}$ of the sample and subsequently mixed until becoming homogeneous to remove casein. Next, $10 \mathrm{~mL}$ of $95 \%$ alcohol was added and the mixture was shaken 15 times. The resulting mixture was added to $25 \mathrm{~mL}$ of ethyl ether, shaken for $1 \mathrm{~min}$, then $25 \mathrm{~mL}$ of petroleum was added and shaken again for $1 \mathrm{~min}$. Finally, the sample was centrifuged at $600 \mathrm{rpm}$ for 30 secs to separate the ether and water phases (pink coloured) and then dried at $\pm 100^{\circ} \mathrm{C}$ for 30 mins in a vacuum oven at $70-75^{\circ} \mathrm{C}$ for 7 mins until a constant weight was measured with the formula:

$$
\text { Fat } \%=\frac{(\text { flask weight }+ \text { fat })-(\text { Flask weight }- \text { Residual weight })}{\text { Sample weight }} \times 100
$$

\subsection{Protein analysis}

The $2 \mathrm{~g}$ of the sample was poured into a Kjeldahl flask and $5 \mathrm{~g}$ of $\mathrm{K}_{2} \mathrm{SO}_{4}, 200 \mathrm{mg}$ of $\mathrm{CuSO}_{4}$, and $30 \mathrm{~mL}$ of concentrated $\mathrm{H}_{2} \mathrm{SO}_{4}$ were added, homogenized, and distilled. The distillate was filled with a standard solution of $0.1 \mathrm{~N} \mathrm{HCl}$ in $50 \mathrm{~mL}$ and three drops of $1 \%$ phenolphthalein indicator were added and titrated with a $0.1 \mathrm{~N}$ standard $\mathrm{NaOH}$ solution until a constant pink colour appeared (AOAC, 2006). The protein assay was done with the formula:

Protein $(\% \mathrm{~N})=\frac{(\mathrm{mL} \text { titration sample }-\mathrm{mL} \text { blank titration })}{\text { Sample weight }} \times 100 \% \times 14.008$

\subsection{Dietary analysis}

A $0.5 \mathrm{~g}$ sample was combined with $0.1 \mathrm{~mL}$ of an alpha-amylase enzyme and heated and stirred at $100^{\circ} \mathrm{C}$ for $15 \mathrm{~min}$. The sample was then cooled and $20 \mathrm{~mL}$ of distilled water and $5 \mathrm{~mL}$ of $1 \mathrm{~N} \mathrm{HCl}$ were added. Next, 
$1 \mathrm{~mL}$ of $1 \%$ pepsin enzyme was added and the mixture was warmed in a water bath for $1 \mathrm{hr}$. After $1 \mathrm{hr}, 5 \mathrm{~mL}$ of $1 \mathrm{~N} \mathrm{NaOH}$ and $0.1 \mathrm{~mL}$ of a beta-amylase enzyme were added and again incubated in a water bath for $1 \mathrm{hr}$. Next, the sample was washed with ethanol and acetone, dried in an oven at $105^{\circ} \mathrm{C}$ for $24 \mathrm{hrs}$, cooled in a desiccator, and weighed to determine the insoluble dietary fibre weight. The volume was adjusted to $100 \mathrm{~mL}$ of filtrate and $400 \mathrm{~mL}$ of $95 \%$ warm ethanol was added. The filtrate was allowed to settle for $1 \mathrm{hr}$ after which it was filtered with ash-free filter paper and washed again with ethanol and acetone. The filtrate was then dried in an oven at $105^{\circ} \mathrm{C}$ for $24 \mathrm{~h}$ and finally placed in a desiccator to weigh the dissolved dietary fibre.

\subsection{Total phenolic content analysis}

The total phenolic assay was performed using the Folin-Ciocalteau method and the gallic acid standard. The data obtained were expressed in milligrams of gallic acid equivalent to $1 \mathrm{~g}$ of dry extract (Ivanov and Dimitrova, 2019).

\subsection{Antioxidant activity analysis}

Antioxidant activity was analysed following the DPPH radical scavenging method and expressed as an $\mathrm{IC}_{50}$ value. The sample was prepared in several concentrations. Each concentration consisted of $0.1 \mathrm{~mL}$ added with $5 \mathrm{~mL}$ of DPPH solution $(0.00039 \mathrm{~g}$ in $1 \mathrm{~L}$ of methanol), followed by homogenization. The mixtures were then incubated at room temperature in a dark room for 30 mins. The colour of the mixture would change due to the reaction with the DPPH reagent. The samples were then spectrophotometrically measured at a $517 \mathrm{~nm}$ wavelength. The inhibition values obtained were then calculated as the $\mathrm{IC}_{50}$ value (Srivastava et al., 2015).

\subsection{Total lactic acid bacteria}

The total lactic acid assay was performed using MRS agar with a pour plate method. The $1 \mathrm{~mL}$ sample was mixed with a $9 \mathrm{~mL}$ of sterile $0.85 \% \mathrm{NaCl}$ solution and homogenized for $1 \mathrm{~min}$, to make a dilution $10^{-1}$. Concurrently, similar sample dilution solutions (aliquots) were made for series $10^{-2}-10^{-7}$. Samples of $1 \mathrm{~mL}$ were taken from each dilution series and placed onto sterile Petri dishes, followed by the addition of $10 \mathrm{~mL}$ of MRS agar warmed to $45^{\circ} \mathrm{C}$. Homogenization was done by shifting the Petri dish to form a figure eight. After the media solidified, the plates were turned upside down and incubated at $37^{\circ} \mathrm{C}$ for $48 \mathrm{hrs}$. The bacteria colonies were counted with a colony counter based on the appearance of clear zones with specific shapes (Daroonpunt et al., 2016).

\section{$2.11 \mathrm{pH}$ analysis}

The $\mathrm{pH}$ analysis was performed with a Mettler Toledo (Singapore) $\mathrm{pH}$ meter calibrated with a standard buffer solution of $\mathrm{pH} 4$ and $\mathrm{pH} 7$ for 15-30 mins. The electrodes were then rinsed with distilled water and dried. A sample of $5 \mathrm{~mL}$ was immersed in electrodes for the $\mathrm{pH}$ measurement. The electrodes were left until stable data were obtained and the results were recorded directly from the $\mathrm{pH}$ meter display (Ly et al., 2020).

\subsection{Total acid analysis}

A $10 \mathrm{~mL}$ sample was poured into an Erlenmeyer tube and three drops of $1 \%$ phenolphthalein were added. The sample was then titrated with a standardized $0.1 \mathrm{~N} \mathrm{NaOH}$ solution, giving it a pink colour. The total acid was calculated with the formula:

$$
\text { Total Acid }(\%)=\frac{\mathrm{mL} \mathrm{NaOH} \times \mathrm{N} \mathrm{NaOH} \times 90 \times 100}{m l \text { sample } \times 1000}
$$

\subsection{The preference tests}

The preference test was based on 30 semi-trained panellists (Ademosun et al., 2019) and based on their preferred colour, aroma, texture, and flavour of the yogurt. A five-point scale were used: 1 - dislike, 2 moderate dislike, 3 - neutral, 4 - moderate like, 5 - like.

\subsection{Statistical analysis}

This study was conducted as a triplicate and analysed using ANOVA. If significant discrepancies were found, Tukey's HSD test would be carried out. Data were processed with SPSS 23.

\section{Results and discussion}

\subsection{Protein}

All yogurts with $C$. racemosa had a protein content of $2.35-2.60 \%$, as shown in Table 1 , similar to the $2.35 \%$ protein content of commercial yogurt. The treatment of lactic acid bacteria on fermentation did not affect the protein content of the yogurt, which concurred with the findings reported by other researchers (Obi et al., 2016; Tenea and Suarez, 2020), who combined lactic acid bacteria $L$. bulgaricus and S. thermophilus with $L$. bulgaricus and $L$. fermentum. During the fermentation process, proteins may break into lactic acids and nonnitrogen proteins, making them undetectable by the ntotal protein method. It indicated that yogurt with $C$. racemosa had higher protein contents compared to yogurt moringa leaf fermented with $L$. bulgaricus (Rahmawati, 2017). Yogurt fermentation involves two exponential phases of bacterial growth separated by a transition phase. The first exponential phase indicates the growth of $S$. thermophilus at a neutral $\mathrm{pH}$ and requires 
Table 1. Chemical characteristics of yogurt

\begin{tabular}{cccccc}
\hline Sample & Protein (\%) & Fat (\%) & Dietary Fibre (\%) & Total phenolic content (mg GAE/g) & Antioxidant activity (ppm) \\
\hline A & $2.52 \pm 0.30^{\mathrm{a}}$ & $0.60 \pm 0.03^{\mathrm{b}}$ & $2.57 \pm 0.25^{\mathrm{d}}$ & $0.10 \pm 0.01^{\mathrm{b}}$ & $191.79 \pm 2.80^{\mathrm{c}}$ \\
B & $2.60 \pm 0.22^{\mathrm{a}}$ & $0.46 \pm 0.02^{\mathrm{a}}$ & $1.78 \pm 0.06^{\mathrm{c}}$ & $0.10 \pm 0.01^{\mathrm{b}}$ & $175.07 \pm 3.28^{\mathrm{b}}$ \\
C & $2.35 \pm 0.12^{\mathrm{a}}$ & $0.45 \pm 0.02^{\mathrm{a}}$ & $1.27 \pm 0.04^{\mathrm{b}}$ & $0.11 \pm 0.01^{\mathrm{b}}$ & $183.58 \pm 10.19^{\mathrm{c}}$ \\
Commercial & $2.35 \pm 0.12^{\mathrm{a}}$ & $0.87 \pm 0.02^{\mathrm{c}}$ & $0.93 \pm 0.12^{\mathrm{a}}$ & $0.04 \pm 0.00^{\mathrm{a}}$ & $138.69 \pm 6.36^{\mathrm{a}}$ \\
\hline
\end{tabular}

Values are presented as mean \pm SD. Values with different superscripts in the same column are significantly different $(\mathrm{P}<0.05)$.

more availability of free amino acids than L. bulgaricus. In this phase, $S$. thermophilus uses more oxygen, thus supporting $L$. bulgaricus unable to grow at high oxygen conditions. In the transition phase, $S$. thermophilus slows due to the lack of free amino acids. In this phase, $S$. thermophilus cannot break down milk proteins to produce amino acids, so the role of L. bulgaricus is significant. L. bulgaricus can break down milk protein to produce amino acids that can support the growth of $S$. thermophilus in the second exponential phase (Sieuwert, 2016). The process leads to lower protein value in yogurt fermented with the combination of L. bulgaricus and $S$. thermophilus than the other treatments even though it is not statistically significant.

\subsection{Fat}

Table 1 shows that yogurt in this study contained fat ranging from 0.45 to $0.60 \%$, which is lower than the $0.87 \%$ in commercial yogurt. The low-fat content in yogurts $\mathrm{A}, \mathrm{B}$, and $\mathrm{C}$ was due to the use of low-fat milk as the raw material. These results are in accordance with Singh et al. (2016) who reported that the fat content of low-fat yogurt with added fruit extracts ranges from 0.44 to $1.6 \%$. Yogurts B and C contained less fat than yogurt A because lipolysis by lactic acid bacteria during the fermentation process converted fat into fatty acids, decreasing the fat content. The lactic acid bacteria strains used affected the outcome, especially $S$. thermophilus which plays a role in the long-chain fatty acid formation, and Lactobacillus requiring a longer time to degrade it (Widyastuti et al., 2014; Sieuwert, 2016; Chen et al., 2017). Thus, yogurt fermented with S. thermophilus contained less fat than with L. bulgaricus.

\subsection{Dietary fibre}

Table 1 shows the different lactic acid bacteria affect the dietary fibre content of yogurt. In this study, yogurt A had a higher dietary fibre content than yogurts B, C, and commercial yogurt. Lactobacillus bulgaricus is a superior starter culture for the fermentation of carbohydrates into dietary fibre than the other bacteria used in this study. Sorensen et al. (2016) demonstrated $L$. bulgaricus and $S$. thermophilus's inability to ferment sugars, mainly glucose and galactose. Its combination produces low glucose, and lactic acid bacteria alone can optimize their activity in fermenting lactose. During the fermentation process, $\mathrm{pH}$ decreased due to organic acid formation, mainly in the form of lactic and acetic acids. An increase in organic acid may lead to the activation of endogenous enzymes that play a role in the degradation process of biopolymer components. The fermentation process may also activate the $\beta$-glucosidase enzyme, which breaks down starch into glucose and dextrin. Finally, lactic acid bacteria may activate extracellular enzymes, such as amylase and pullulanase, which can break down starch into oligosaccharides and undigested starch components (Sari et al., 2017; Tsafrakidou et al., 2020). C. racemosa is a source of carbohydrate and contains $48.97 \%$ total carbohydrate and $11.51 \%$ fibre content (Bhuiyan et al., 2016). The low dietary fibre content of yogurt is presumably related to the combination of two starter cultures, such as $S$. thermophilus and L. bulgaricus. Tsafrakidou et al. (2020) reported that two Gram-positive thermophilic organisms did not properly ferment sugar into a simple compound. Dietary fibre is good for our health and especially beneficial to the digestive system. The consumption of dietary fibres is not linked to increased blood sugar levels, so it can be consumed without increasing the risk of contracting diabetes mellitus (Tsafrakidou et al., 2020). Furthermore, Beretta et al. (2018) noted that dietary fibre consumption reduces blood sugar levels in patients with diabetes mellitus type one.

\subsection{Total phenolic content}

Table 1 shows the total phenolic content in yogurt with added $C$. racemosa as a raw material ranged from 0.10 to $0.11 \mathrm{mg} \mathrm{GAE} / \mathrm{g}$, higher than the $0.04 \mathrm{mg} \mathrm{GAE} / \mathrm{g}$ of commercial yogurt. Yap et al. (2019) explained that C. racemosa extracted with methanol has a total phenolic content of $10.33 \mathrm{mg} \mathrm{GAE} / \mathrm{g}$. According to Taneva and Zlatev (2020) and Adebo and Medina-Meza (2020), goji berries yogurt had high total phenolic contents. Lactic acid bacteria did not affect the total phenolic content, Nisa et al. (2019) also found that fermentation using different lactic acid bacteria did not affect the total phenolic content in fermented rice bran.

\subsection{Antioxidant activity}

Table 1 shows antioxidant activity expressed as an $\mathrm{IC}_{50}$ value. Lactic acid bacteria affected the $\mathrm{IC}_{50}$ of $C$. 
racemosa yogurt. The antioxidant activity of yogurt fermented with $S$. thermophilus was higher than yogurt fermented with $L$. bulgaricus and yogurt fermented with a combination of $L$. bulgaricus and $S$. thermophilus. Milk fermented with lactic acid bacteria had higher antioxidant activity than non-fermented milk. During the fermentation process, proteins, carbohydrates, and fats were broken down into amino acids, peptides, organic acids, and other compounds that are beneficial to our health. Amino acids and peptides have anti-hypertensive properties, increase antioxidant activity, and inhibit fat peroxidation (Gjorgievski et al., 2014). The high antioxidant activity in yogurt B was due to $S$. thermophilus more effectively degrading amino acids than L. bulgaricus (Sieuwerts, 2016). Antioxidant activity is proportional to the total phenol content in yogurt. Fermentation is known to increase the total phenol content due to the change in temperature, $\mathrm{pH}$, fermentation time, and the presence of lactic acid bacteria which can break phenolic bonds and increase antioxidant activity (Tsafrakidou et al., 2020). This study's results were in line with Gjorgievski et al. (2014) who found that milk fermented with monocultural lactic acid bacteria strains produced higher antioxidant activity than milk fermented with multicultural lactic acid bacterial strains.

\subsection{Total lactic acid bacteria and $p H$}

C. racemosa yogurt with different strains of lactic acid bacteria had a significant effect on growth. Yogurt fermented with $S$. thermophilus contained more lactic acid bacteria than yogurt fermented with L. bulgaricus (Figure 1). However, combining S. thermophilus and $L$. bulgaricus produced a symbiotic mutualism where $S$. thermophilus was more active in the first phase of the fermentation process to degrade amino acids and trace elements than $L$. bulgaricus. Furthermore, $S$. thermophilus used more oxygen, which is beneficial for L. bulgaricus as it cannot withstand the presence of high amounts of oxygen (Sieuwerts, 2016). The growth of lactic acid bacteria is influenced by the fermentation duration (Taleghani et al., 2016) and the $\mathrm{pH}$ of yogurt. Optimal conditions for $S$. thermophilus range from 4 to $4.5 \mathrm{pH}$. Decreasing acidity would inhibit the growth of $S$. thermophilus (Chramostová et al., 2014). Yogurts B and $\mathrm{C}$ had 4.83 and $5.04 \mathrm{pH}$ respectively, similar to Chramostová et al. (2014) who found that the total lactic acid bacteria ranging from 7 to $8 \log \mathrm{CFU} / \mathrm{mL}$ had a $\mathrm{pH}$ of 4.26-4.32. The low $\mathrm{pH}$ of yogurt is caused by organic acids, mainly lactic acid, and acetic acid during the fermentation process (Chen et al., 2017).

\subsection{Total acid}

Fermentation by lactic acid bacteria converted carbohydrates into organic acids, which were summed up as the total acid (Figure 1). Lactic acid bacteria convert carbohydrates in milk, such as lactose, into lactic acid. Lactic acid production was affected by lactic acid bacteria strains. L. bulgaricus and S. thermophilus are known to produce lactic acid with different isomers, such as $\mathrm{D}(-)$ and $\mathrm{L}(+)$ lactic acid, through heterofermentative pathways. This process also generates acetic acid (Widyastuti et al., 2014; Gezginc et al., 2015; Chen et al., 2017). Table 2 shows that yogurt in this study had a total acid range of $0.64-0.71 \%$. Yogurt with C. racemosa produced less acid than commercial yogurt $(0.85 \%)$. Gezginc et al. (2015) explained the optimal conditions for L. bulgaricus and S. thermophilus to produce lactic acid through fermentation, such as an incubation temperature of $42^{\circ} \mathrm{C}$. Incubation at $37^{\circ} \mathrm{C}$ is optimal for both bacteria strains to produce acetaldehyde, which plays a role in giving yogurt its flavour. In this study, incubation and fermentation took place at $37^{\circ} \mathrm{C}$, making the total acid content in yogurt with $C$. racemosa being lower than commercial yogurt to be expected.



Figure 1. Total lactic acid bacteria, $\mathrm{pH}$ and total acid of yogurt sample. Data with different superscripts are significantly different $(\mathrm{P}<0.05)$ for each parameter.

\subsection{The preference tests}

The results of the preference test for C. racemosa yogurt are shown in Table 2. The different lactic acid bacteria played a role in the panelists' preferences for colour, aroma, texture, and flavour. Based on colour, the addition of $C$. racemosa was rated from neutral to moderate like. The green colour of $C$. racemosa yogurt is caused by a natural green pigment named chlorophyll (Sihono et al., 2018). In terms of aroma, the panellists rated the yogurt as moderate like. The aroma came from the formation of acetaldehyde during the breakdown of threonine during the fermentation process (Krisnaningsih and Yulianti, 2015). It was also related to the effectiveness of the combination of L. bulgaricus and $S$. thermophilus at degrading amino acids (Sieuwerts, 
Table 2. Preference test of yogurt

\begin{tabular}{ccccc}
\hline Sample & Colour & Aroma & Texture & Taste \\
\hline A & $2.87 \pm 0.78^{\mathrm{b}}$ & $2.50 \pm 0.68^{\mathrm{a}}$ & $2.37 \pm 0.61^{\mathrm{a}}$ & $2.50 \pm 0.68^{\mathrm{a}}$ \\
B & $3.17 \pm 0.53^{\mathrm{bc}}$ & $3.20 \pm 0.55^{\mathrm{b}}$ & $3.07 \pm 0.45^{\mathrm{bc}}$ & $3.27 \pm 0.52^{\mathrm{b}}$ \\
C & $3.47 \pm 0.68^{\mathrm{c}}$ & $3.63 \pm 0.67^{\mathrm{c}}$ & $3.33 \pm 0.71^{\mathrm{c}}$ & $3.37 \pm 0.49^{\mathrm{b}}$ \\
Commercial & $2.40 \pm 0.56^{\mathrm{a}}$ & $2.90 \pm 0.66^{\mathrm{ab}}$ & $2.70 \pm 0.60^{\mathrm{ab}}$ & $3.03 \pm 0.67^{\mathrm{b}}$ \\
\hline
\end{tabular}

Values are presented as mean $\pm \mathrm{SD}$. Values with different superscripts in the same column are significantly different $(\mathrm{P}<0.05)$.

2016). The texture and flavour of yogurt $C$ were the most preferred. During yogurt processing, L. bulgaricus and $S$. thermophilus play a role in texture production. The texture comes from the total solids and protein content of the yogurt, which gives it firmness. Lactobacilli degrades amino acids in milk into glycine and histidine, which support the growth of streptococci. Combining the two bacteria converted milk sugar to lactic acid, giving it a pleasant flavour and consistency. Acid formation during the fermentation process caused the rearrangement of casein creating a more compact yogurt structure (Mohan et al., 2020). Yogurt has a strong sour taste related to the formation of lactic and acetic acid (Chen et al., 2017). Nowadays, consumers prefer a tasty and less sour taste, which the low $\mathrm{pH}$ resulting from $L$. bulgaricus provides. Combining L. bulgaricus and $S$. thermophilus produced a less sour taste. Sieuwert (2016) found that $S$. thermophilus plays a role in aroma formation, so the combination of L. bulgaricus and S. thermophilus produces yogurt with a mildly sour taste and a desirable aroma.

\section{Conclusion}

Yogurt with Caulerpa racemosa produced a probiotic drink with low fat, tasty, and had functional properties such as total phenolic content, antioxidant $\mathrm{IC}_{50}$ and dietary fibre was better than commercial one. Yogurt made with combination $L$. bulgaricus and $S$. thermophilus (yogurt $C$ ) was the most preferred by panellists.

\section{Conflict of interest}

The authors declare no conflict of interest.

\section{Acknowledgments}

The study was financially supported by the Faculty of Fisheries and Marine Sciences, Diponegoro University, 2020 with grant No. 003/UN7.5.10.2/ $\mathrm{PP} / 2020$.

\section{References}

Adebo, O.A. and Medina-Meza, I.G. (2020). Impact of fermentation on the phenolic compounds and antioxidant activity of whole cereal grains: A mini review. Molecules, 25(4), $927 . \quad \mathrm{https} / / /$ doi.org/10.3390/molecules25040927

Ademosun, O.T., Ajanaku, K.O., Adebayo, A.H., Oloyede, M.O., Okere, D.U., Akinsiku, A.A. and Owolabi, A.O. (2019). Physico-chemical, microbial and organoleptic properties of yogurt fortified with tomato juice. Journal of Food and Nutrition Research, 7(11), 810-814. https://doi.org/10.12691/ jfnr-7-11-9

Agu, K.C., Archibong E.J, Anekwe D.C, Ago C.A, Okafor A.C. and Awah N.S. (2014). Assessment of bacteria present in yogurt sold on awka metropolis. Scholars Journal of Applied Medical Sciences (SJAMS, 2(6D), 3071-3075.

AOAC International. (1992). AOAC Official Method 989.05 Fat in Milk. USA: AOAC.

AOAC International. (2006). Official Methods of Analysis of AOAC International. USA: AOAC.

Beretta, M.V., Bernaud, F.R., Nascimento, C., Steemburgo, T. and Rodrigues, T.C. (2018). Higher fiber intake is associated with lower blood pressure levels in patients with type 1 diabetes. Archives of Endocrinology and Metabolism, 62(1), 40-47. https://doi.org/10.20945/2359-3997000000008

Bhuiyan, M.K.A., Qureshi, S., Kamal, A.H.M., Uddin, S.A. and Siddique, M.A.M. (2016). Proximate chemical composition of sea grapes Caulerpa racemosa (J. Agardh, 1873) collected from a subtropical Coast. Virology and Mycology, 5(2), 158. https://doi.org/10.4172/2161-0517.1000158

Chen, C., Zhao, S., Hao, G., Yu, H., Tian, H. and Zhao, G. (2017). Role of lactic acid bacteria on the yogurt flavour: A review. International Journal of Food Properties, 20(1), S316-S330. https:// doi.org/10.1080/10942912.2017.1295988

Chramostová, J., Mošnová, R., Lisová, I., Pešek, E., Drbohlav, J. and Němečková, I. (2014). Influence of cultivation conditions on the growth of Lactobacillus acidophilus, Bifidobacterium sp., and Streptococcus thermophiles, and on the production of organic acids in fermented milks. Czech Journal of Food Sciences, 32(5), 422-429. https://doi.org/10.17221/616/2013cjfs

Corrieu, G. and Béal, C. (2016). Yogurt: The product and its manufacture. In Encyclopedia of Food and 
Health. Reference Module in Food Science, p. 617624. Elsevier E-Book. https://doi.org/10.1016/B9780-12-384947-2.00766-2

Daroonpunt, R., Uchino, M., Tsujii, Y., Kazami, M., Oka, D. and Tanasupawat, S. (2016). Chemical and physical properties of Thai traditional shrimp paste (Ka-pi). Journal of Applied Pharmaceutical Science, 6(5), 58-62. https://doi.org/10.7324/ JAPS.2016.60509

Gezginc, Y., Topcal, F., Comertpay, S. and Akyol, I. (2015). Quantitative analysis of the lactic acid and acetaldehyde produced by Streptococcus thermophilus and Lactobacillus bulgaricus strains isolated from traditional Turkish yogurts using HPLC. Journal of Dairy Science, 98(3), 1426-1434. https://doi.org/10.3168/jds.2014-8447

Gjorgievski, N., Tomovska, J., Dimitrovska, G., Makarijoski, B. and Shariati, M.A. (2014). Determination of the antioxidant activity in Yogurt. Journal of Hygienic Engineering and Design, 8, 8891.

Ivanov, G.Y. and Dimitrova, M.R. (2019). Functional yogurt fortified with phenolic compounds extracted from strawberry press residues and fermented with probiotic lactic acid bacteria. Pakistan Journal of Nutrition, 18(6), 530-537. https://doi.org/10.3923/ pjn.2019.530.537

Krisnaningsih, A.T.N. and Yulianti, D.L. (2015). Improving the quality of the yogurt with the addition of honey. In Proceeding of International Seminar Improving Tropical Animal Production for Food Security, p. 205-211. Kendari, South Sulawesi, Indonesia: Unhalu Press

Kumar, A., Krishnamoorthy, E., Devi, H.M., Uchoi, D., Tejpal, C.S., Ninan, G. and Zynudheen, A.A. (2017). Influence of sea grapes (Caulerpa racemosa) supplementation on physical, functional, and antioxidant properties of semi-sweet biscuits. Journal of Applied Phycology, 30(2), 1393-1403. https://doi.org/10.1007/s10811-017-1310-4

Ly, D., Mayrhofer, S., Schmidt, J., Zitz, U. and Domig, K.J. (2020). Biogenic amine contents and microbial characteristics of Cambodian fermented foods. Foods, 9(2), 198. https://doi.org/10.3390/ foods 9020198

Rizzoli, R. and Biver, E. (2017). Chapter 29 - Yogurt consumption and impact on bone health. In Shah, N.P. (Ed.). Yogurt in Health and Disease Prevention, p. 507-524. USA: Academic Press. https:// doi.org/10.1016/B978-0-12-805134-4.00029-8

Miklavec, K., Pravst, I., Grunert, K.G., Klopčič, M. and Pohar, J. (2015). The influence of health claims and nutritional composition on consumers' yogurt preferences. Food Quality and Preference, 43, 2633. https://doi.org/10.1016/j.foodqual.2015.02.006

Mohan, A., Hadi, J., Gutierrez-Maddox, N., Li, Y., Leung, I.K.H., Gao, Y., Shu, Q. and Quek, S.Y. (2020). Sensory, microbiological and physicochemical characterisation of functional Manuka honey yogurts containing probiotic Lactobacillus reuteri DPC16. Foods, 9(1), 106. https://doi.org/10.3390/foods9010106

Nisa, K., Rosyida, V.T., Nurhayati, S., Indrianingsih, A.W., Darsih, C. and Apriyana, W. (2019). Total phenolic contentic contents and antioxidant activity of rice bran fermented with lactic acid bacteria. IOP Conference Series: Earth and Environmental Science, 251, 012020. https://doi.org/10.1088/17551315/251/1/012020

Nurjanah, N., Jacoeb, A.M., Asmara, D.A. and Hidayat, T. (2019). Phenol component of fresh and boiled sea grapes (Caulerpa sp.) From Tual, Maluku. Food ScienTech Journal, 1(1), 31-39. https:// doi.org/10.33512/fsj.v1i1.6244

Obi, C., Olugbue, V. and Mpamugo, C. (2016). Yogurt production from powdered milk using mixed lactic acid bacteria starter cultures. Saudi Journal of Pathology and Microbiology, 1(2), 42-49.

Pires, C.L., Rodrigues, S.D., Bristot, D., Gaeta, H.H., Toyama, D.O., Ronald, W., Farias, L. and Toyama, M.H. (2013). Sulfated polysaccharide extracted of the green algae Caulerpa racemosa increase the enzymatic activity and paw edema induced by sPLA2 from Crotalus durissus terrificus venom. Brazilian Journal of Pharmacognosy, 23(4), 635$643 . \quad$ https://doi.org/10.1590/S0102695X2013005000050

Rahman, S.R., Alam, M.Z. and Mukta, S. (2016). Studies on yogurt production using Lactobacillus bulgaricus and Streptococcus thermophilus isolated from market yogurt. Journal of the Sylhet Agricultural University, 3(2), 307-313.

Rahmawati, E. (2017). Protein content, pH, and lactic acid bacteria in yogurt with addition moringa leaves extract and different fermentation period. International Proceedings of Chemical, Biological and Environmental Engineering, 102, 81-86.

Sari, P.M., Puspaningtyas, D.E. and Kusuma, R.J. (2017). Dietary fiber and carboydrate contents of gathotan and gathot as functional food for people with diabetes mellitus. Indonesian Journal of Nutrition and Dietetics, 5(2), 88-92. https:// doi.org/10.21927/ijnd.2017.5(2).88-92

Sarvari, F., Mortazavian, A.M. and Fazeli, M.R. (2014). 
Biochemical characteristics and viability of probiotic and yogurt bacteria in yogurt during the fermentation and refrigerated storage. Applied Food Biotechnology, 1(1), 55-61. https:// doi.org/10.22037/afb.v1i1.7125

Sieuwerts, S. (2016). Microbial interactions in the yogurt consortium: current status and product implications. SOJ Microbiology and Infectious Diseases, 4(2), 15. https://doi.org/10.15226/sojmid/4/2/00150

Sihono, S., Tarman, K., Madduppa, H. and Januar, H.I. (2018). Metabolite profiles and antioxidant activity of Caulerpa racemosa with different handlings. Squalen Bulletin of Marine and Fisheries Postharvest and Biotechnology, 13(3), 93-100. https://doi.org/10.15578/squalen.v13i3.355

Singh, K., Chandra, R. and Shukla, S. (2016). Studies on chemical properties of low-fat frozen yogurt prepared with mixing of varying pulp level of different fruits. The Pharma Innovation Journal, 5 (10), 122-124.

Sorensen, K.I., Curic-Bawden, M., Junge, M.P., Janzen, T. and Johansen, E. (2016). Enhancing the sweetness of yoghurt through metabolic remodeling of carbohydrate metabolism in Streptococcus thermophilus and Lactobacillus delbrueckii subsp. bulgaricus. Applied and Environmental Microbiology, 82(12), 3683-3692. https:// doi.org/10.1128/AEM.00462-16

Srivastava, P., Prasad, S., Nayeem, M. and Prasad, M. (2015). Analysis of antioxidant activity of herbal yogurt prepared from different milk. The Pharma Innovation Journal, 18(43), 18-20.

Taleghani, H.G., Najafpour, G.D. and Ghoreyshi, A.A. (2016). A study on the effect of parameters on lactic acid production from whey. Polish Journal of Chemical Technology, 18(1), 58-63. https:// doi.org/10.1515/pjct-2016-0010

Tenea, G.N. and Suarez, J. (2020). Probiotic potential and technological properties of bacteriocinogenic Lactococcus lactis Subsp. lactis UTNGt28 from a Native Amazonian fruit as a yogurt starter culture. Microorganisms, 8(5), 733. https://doi.org/10.3390/ microorganisms 8050733

Taneva, I. and Zlatev, Z. (2020). Total phenolic contentic content and antioxidant activity of yogurt with goji berries (Lycium barbarum). Scientific Study and Research: Chemistry and Chemical Engineering, Biotechnology, Food Industry, 21(1), 125-131.

Tapotubun, A.M., Matrutty, T.E.A.A., Tapotubun, E.J., Mailoa, M.N. and Fransina, E.G. (2018). The sensory characteristic of caulerpa jelly candy based on the consumers acceptance. Science Nature, 1(1), 15-21. https://doi.org/10.30598/volliss1pp015021year 2018

Tsafrakidou, P., Michaelidou, A.M. and Biliaderis, C.G. (2020). Fermented cereal-based products: Nutritional aspects, possible impact on gut microbiota and health implications. Foods, 9(6), 734. https:// doi.org/10.3390/foods 9060734

Undugoda, L. and Nilmini, A. (2019). Effect of lactic acid microbial ratio of yogurt starter culture in yogurt fermentation and reduction of post acidification. Journal of Food and Industrial Microbiology, 5(1), 130.

Weerathilake, W.A.D.V, Rasika, D.M.D., Ruwanmali, J.K.U. and Munasinghe, M.A.D.D. (2014). The evolution, processing, varieties and health benefits of yogurt. International Journal of Scientific and Research Publications, 4(1), 2250-3153.

Widyastuti, Y., Rohmatussolihat and Febrisiantosa, A. (2014). The role of lactic acid bacteria in milk fermentation. Food and Nutrition Sciences, 5(4), 435 -442. https://doi.org/10.4236/fns.2014.54051

Yap, W.F., Tay, V., Tan, S.H., Yow, Y.Y. and Chew, J. (2019). Decoding antioxidant and antibacterial potentials of Malaysian green seaweeds: Caulerpa racemosa and Caulerpa lentillifera. Antibiotics, 8(3), 152. https://doi.org/10.3390/antibiotics 8030152 